\title{
The Effects of Demand Pull Strategies on Sustainable Development in Manufacturing Industries
}

\author{
Anuj Singla \\ Assistant Professor, Department of Mechanical Engineering \\ Chandigarh Engineering College, Landran, Mohali, Punjab, India \\ Dr. I.P.S. Ahuja \\ Professor, Department of Mechanical Engineering \\ Punjabi University, Patiala, Punjab, India \\ Dr. A.P.S. Sethi \\ Professor, Department of Mechanical Engineering \\ Baba Banda Singh Bahadur Engineering College, Fatehgarh Sahib, Punjab, India
}

\begin{abstract}
The purpose of the review is to have a perception of Demand Pull (DP) strategies to extend essential capabilities in manufacturing industries and to analyze the experiences of the developed and developing economies. The study reveals that the encouraging DP strategies enhance the key skills in the framework of a company. Furthermore, it emphasizes that the DP strategies makes significant impacts on the sustainable development of a manufacturing industry. The significance of demand pull policies in manufacturing companies in less developed economies has not been much reported. A model can be developed by the achievement levels of industries, which will help in attaining core principles and priorities. The paper elaborates the linkages between technological capabilities and demand, so as to meet the customer's needs in time. It explores the compliance of products as per government regulations and how the companies manage the demand pull when the government stringently implements its policies. Various papers and relevant articles have been studied and reviewed from different journals and linked with criterion related to demand pull for sustainable development in manufacturing enterprises.
\end{abstract}

Keywords - Demand pull, Sustainable development, Manufacturing industries, Technology.

\section{INTRODUCTION}

Today's manufacturing scenario is illustrated by accelerated changes in market, rise in diversity of items and enhanced competitive strategies. The changes in product demand respond quickly to cope with competitive markets. Nowadays, most of the firms are using similar manufacturing processes and systems etc., therefore the competition is not only based on manufacturing technology, but how well the firm governs the technology apropos its consumers. The firms must consider innovation as an inbuilt, ongoing process with continuous improvement in mind. The efforts give best output if they integrate both market and technology forces. Internationally focused companies require a vigorous manufacturing corporation. The commitment of technology and its executives plays a vital role in raising the standard of manufacturing industries.

As per Demand Pull, an innovation has been produced by the R\&D in light of a recognized market need. Demand pull inflation is likely to emerge when total demand in an economy overtakes total supply. It involves inflation rising as real gross domestic product rises and unemployment falls. This is generally portrayed as too much money chasing too few goods. 


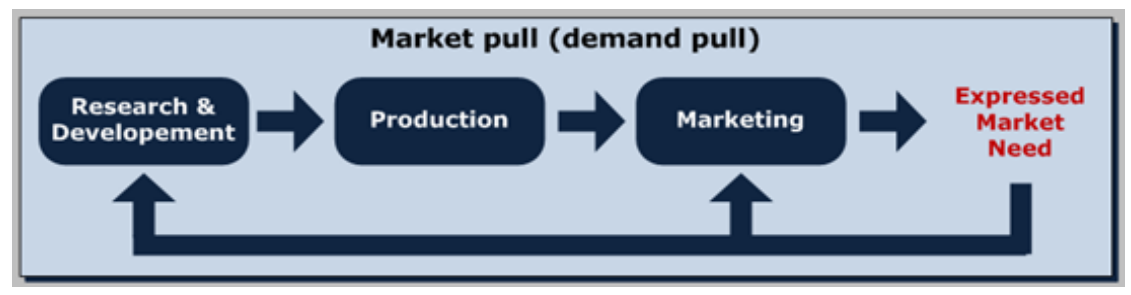

Figure 1: Demand Pull strategy

Sastry (2011) reported that business being the most prominent sector is the main energy of a market. Moreover, the industrialists impact the economy, employment and political arrangements and the progressions are favoring business. As a result numerous national companies have become global and strongly contend with established multinationals. Yadav (2012) stated that trade is a primary indicator among the various aspects of globalization. It includes ever changing formats of the organization which are more extensive as compared to the past. Over the time several emerging economies have influenced the demand of the products in global market and proved to be the modern drivers of development.

Certainly, numerous definitions of sustainability are suggested over the time. According to World Commission on Environment and Development, sustainable development is a procedure of progress in which the exploitation of assets, the direction of ventures, the introduction of innovative advancement, and institutional transformation are made steady eventually according to the existing demand. Sustainable progress and social security can only be accomplished if humans are able to make overall employments and better living conditions for human ethical quality. Global technology push and demand pull along with industrial revolution leads to competitive sustainable manufacturing (Jovane et al., 2008).

Schon (1967) initially presented technology push and demand pull systems. He suggested that technology push and demand pull are the essential inspirations and dynamic efforts behind the diversification of a new technology. Technology push supports the thought that innovation is stimulated by science and thus activates technology. On the contrary, demand pull proposes that client needs are the key simulators of technology adoption. It was inferred that the major role is played by demand pull, so the needs for innovation should be given careful consideration than technical ability (Chau and Tam, 2000).

Manufacturing is termed as the conversion of raw materials and data into valuables for the fulfillment of human demands. It promotes prosperity into the society. Stimulating excellence in manufacturing, acts as a crucial objective for both industry and nation in the subsequent time (Chryssolouris et al., 2013).

\section{LiteRATURE REVIEW}

An understanding of demand pull strategies uncovers that extremely constrained information is available concerning sustainable development activities towards harnessing essential abilities in the manufacturing industries. Thusly, in the current connection, a review of previous literature highlighting various issues and measures has been conducted in this paper. The literature review is based on the issues discussed below:

\subsection{Government regulations}

A government policy articulation is an assertion of a government's political exercises, arrangements and goals related to a solid cause. The government regulations have a precise impact on the demand of various products in the market. The literature from the past on government policies effecting demand and demand pull, by various authors is elaborated in the following section:

The issues related to environmental regulation was examined by Ashford and Heaton (1976). Their work is based on the subject related to environmental policies framed by the government and how it affects the demand pull. They focused on the fact that whether the long-term benefits from environmental policies are justified against the high short-term expenses. It was investigated that some issues are crucial enough to evaluate the costs and advantages of environmental control. The authors suggested that the environmental regulations may not only decrease the total cost to the society but may reduce prices as well, which may lead to rise in demand. New environmental regulations have made large markets accessible for new pollution monitoring and control devices for innovative development strategy. It was observed that the government regulations concerned with safety and environment seem to have significant effect and positive approach towards prosperity of the society. 
According to Rothwell (1992) while the government activities were at high states in mid 1960s to 1970s, the next decade faced a substantial pattern towards deregulation. Subsequent to mid-1980s, with adverse effects of environmental contamination, there has been enough pressure to apply the government norms stringently for environmental issues. As a result, government regulations has negative impact on manufacturing companies, because the demand of products increases manifolds and the industries are unable to meet that. For this, the researcher recommended the ways to optimize the adverse effects of environmental policies on the industries. It was concluded that a prominent coordination between environmental policy, technology policy and demand pull strategies for environmental protection is desirable.

Taylor et al. (2005) investigated how the government policies impel innovation in the operations of invention and adoption. Their research applied numerous quantitative and qualitative degrees of development to various demand pull strategies. The government plays a vital role in empowering information exchange through specialized conferences, as well as specialized research groups. Johnstone et al. (2010) examined the impact of ecological activities on technological advancement in the field of renewable energy. They analyzed the patent information on a board of 25 nations over the period 1978-2003. It was found that social approach assumes a critical part in deciding patent applications of different products. It was inferred that distinctive sorts of approach instruments are effective for various renewable energy sources.

The associations like the United Nations Framework Convention on Climate Change (UNFCCC) and Kyoto Protocol (KP) support clean energy technology as key to a prudential emission reduction framework. This work created demand pull situations on its most intensive areas (power, iron and steel, and cement preparations). It was concluded that the DP schemes are not worthwhile for lessening the pollution of a provincial framework inside a multi-divisional energy system (Rout, 2011).

Gil-Garcia et al. (2014) proposed that exercises that put resources into development to accomplish more active and versatile government strategies are described by smart government. However, there is no concurrence between emerging technology and development in the public sector. It leads to fluctuations in the price and demand of products. Aggregately, the researchers gave viewpoint on the strategy of smart governments and activities on how governments are opening up and changing administration activities to act more smartly. It was presumed that government could be seen as an imaginative blend of ever changing technology and development in the public division. At times the technical segment is the most crucial one, yet in different cases the technology is a minor part of progression of changes and advancements.

According to Hannon et al. (2015), demand pull methodologies of government introduces an efficient method to fortify the administration based plans of action, commonly known as Product-Service Systems (PSS). It includes supply based plans to fulfill social necessities in environmentally feasible way; however the usage of PSS remain isolated due to some crucial obstructions. It was reasoned that the research strengthens the requirement for energy proficiency commitments that includes both energy suppliers and purchasers.

Costantini et al. (2015) explored the impacts of TP-DP policies in forming technological impressions in the biofuels segment. The work demonstrated that scientific skills and environmental control activates innovative exercises in the bio-fuels industry with technology push and demand pull, both as critical drivers of innovation. The government is motivating industries to enhance their technological capabilities to meet the rise in demand of biofuels. It was inferred that, the combination of the two drivers is required to begin a positive dynamic development of the technological track in the bio-fuels segment and both are pertinent in forming the rate of technological revolution.

\subsection{Unionized labor}

Labor unions are perceived as representatives of laborers in numerous industries. Their activity is to provide advantages, proper wages and working circumstances to their workers and the union represents their members in case of any disputes with administration. The researchers relate the issues of unionized labor which the industries face with the rise in demand of their products. Some of them are summarized below:

According to Walker (1993) the division of labor is an unnoticed classification of an established economy. In an industry, the workers prefer to adopt better methodology to build designed products to make the customers purchase better quality and lower-priced products. On the flipside, sometimes the labor union resists the changes in the existing products which may affect the demand. It was concluded that, an industry cannot turn its powers to the extreme good without an extensive, more ideal organization of the laborers and the working class. There are numerous ramifications of a union which may abuse the presence of company's labor conformity costs (Modesto and Thomas, 2001). The authors dissected the implications of aggregate bargaining in the vicinity of labor 
adjustment costs. It was inferred that conformity costs affect the pace of modification of employment and it is the presence or the nonattendance of a commitment capacity of the union that matters.

Lingens (2003) explored the relationships among unemployment and development. A differentiation between low and highly expert labor has been made and it was accepted that a union deals over the less efficient labor wages. This leads to unemployment, yet the impact of development is vague. Surely, the higher pay will suppress expected benefits, which is not good for development and the compensation to highly-skilled workers in the industries decreases. If efficient bargaining is allowed, the unionization of the labor become unambiguously awful for development in light of the fact that the main union impact is the bringing down of monopoly benefits which demoralizes pioneers.

According to Bastos et al. (2009) the company specific plans which decide the wages plays a major role in the industry wage platform. It is demonstrated that both the company's income platform and the normal compensation paid are explicitly connected with the level of firm heterogeneity in the business. It was concluded that, it is important to maintain the salaries of the workers up to a certain level, so as not to face any wage negotiations during the high demand of the company's products. Aloi et al. (2009) were of the view that different nations have contrast in their labor market organizations; one nation has a focused work market while the other is unionized. It was presumed that laborers must support dictatorship in a unionized nation, yet restricts it in the non-unionized nation. Lommerud et al. (2012) stated that the incentives are influenced by labor enterprise foundations in multinational ventures. If the laborers are synchronized, push for innovation exchange is partially administered by firm's desire to check trade union force. Higher union dealing with power prompts more technology exchange along with two unique measurements, expertise and quality.

\subsection{Sustainable Development}

Sustainable development is the development that addresses the needs of present without compromising the requisites of future generations to meet their own needs (Brundtland, 1987). It requires that we see the world as a system: a system that connects space and a system that connects time.

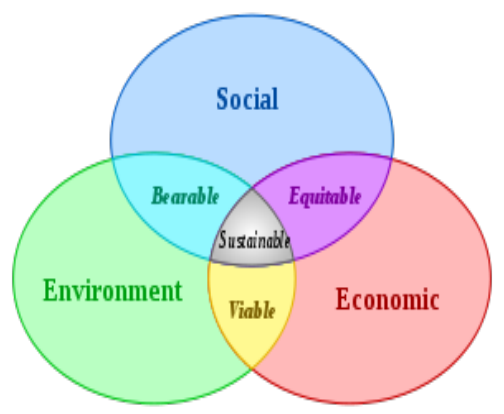

Figure 2: Key dimensions of sustainable development.

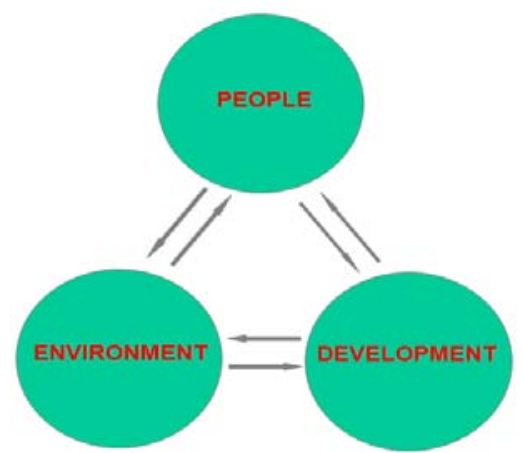

Figure 3: Inter-relation of people, environment and development.

The four essential dimensions to measure sustainable development (Holden et al., 2014) are:

1. ensuring long-term ecological sustainability: the word sustainability came from ecological science. It was developed to express the conditions that should be available for the biological system to manage itself over the long time.

2. fulfilling basic human needs: it is an indispensable element of sustainable development. The idea of need is inculcated in the meaning of sustainable development. Thus, fulfilling essential human needs and guaranteeing long term biological manageability constitute vital preconditions for sustainable development.

3,4. encouraging inter- and intra-generational equity: the basic necessity to conserve the earth's biological systems has led several authors to infer that the idea of sustainable development should be understood as pertaining exclusively to physical sustainability. On the other hand, the Brundtland Report says no to such a conclusion. It expressed that even physical sustainability cannot be ensured unless development policies pay attention to such considerations as changes in access to assets and in the distribution of costs. Furthermore, it guarantees that social 
equity among generations should consistently be continued to equity within each generation. Thus, social equity as an essential part of sustainable development has two measurements, time and space. From this point of view, sustainable development has results for equity both globally and nationally within and between generations.

\begin{tabular}{|c|l|l|}
\hline S.No. & \multicolumn{1}{|c|}{ Parameters } & \multicolumn{1}{c|}{ To measure these parameters } \\
\hline 1 & Economic & $\begin{array}{l}\text { Keeping up a sustainable population. } \\
\text { Keeping up efficiency and benefit of environment and natural resources. }\end{array}$ \\
\hline 2 & Ecological & $\begin{array}{l}\text { Embracing ecological administration force in policy and decision making. } \\
\text { Securing the environment and conserving natural assets. }\end{array}$ \\
\hline 3 & Technological & $\begin{array}{l}\text { Advancing appropriate management of wastes and residuals. } \\
\text { Embracing environment-friendly technologies. }\end{array}$ \\
\hline 4 & Political & $\begin{array}{l}\text { Empowering the people. } \\
\text { Retaining peace and order. }\end{array}$ \\
\hline 5 & Socio-cultural & $\begin{array}{l}\text { Encouraging resource access and upholding property rights. } \\
\text { Encouraging environmental awareness, imparting environment morality and } \\
\text { supporting environment management decision. }\end{array}$ \\
\hline 6 & Institutional & Enhancing institutional ability to govern sustainable development. \\
\hline
\end{tabular}

Table 1: Parameters of sustainable development.

The various authors have associated sustainable development with demand pull and which is elaborated with the help of following section:

A Fit Manufacturing Framework (FMF) was suggested by Pham and Thomas (2012), the reception of which made organizations financially sustainable and operates successfully as per the demand pull in the global business sector. Singh and Debnath (2012) suggested a model to comprehend the connection among different empowering agents of Clean Development Mechanism (CDM) to know their level of reliance and effectiveness. The model displayed different guidelines of sustainable development and it was concluded that sustainable improvement in an industry can be achieved by focusing important objectives and operations which fulfills the demand of customers.

Bogue (2014) proposed sustainable manufacturing ideas and methodology. He initially considered different government affairs and then examined the guidelines with specific design. He inferred that sustainable development plays a basic role in routine production and manufacturing yet minimally affects the demand. According to Blohmke (2014) merging climate change mitigation and sustainable development is pivotal for the transition towards low carbon growth. His work is associated with a combination of technology exchange and particular aspects of technology and demand with sustainable development goals. He was of the view that local technology needs and socio-technical circumstances are important towards economic development induced by technology transfer. It was concluded that the global climate policy architecture has been under review and is about to change.

Bohnsack et al. (2014) were of the perspective that sustainable developments stimulate the business processes, particularly in enterprises that depend totally on the utilization of fossil fuels. Wagner et al. (2014) stated that according to Brundtland report sustainable development can serve as a sensible beginning for sustainable business improvement.

\subsubsection{Productivity}

Productivity is the ratio of output to inputs used in the production operation. It is an average apportion of the efficiency of production. It acts as a critical element in proficiency of companies as well as countries. Rising national productivity may uplift the quality of life because more income improves citizen's ability to purchase goods and services which will lead to improved standard of living. A review based on productivity issues related to sustainable development is presented as follows:

The production capacities of different industries were assessed (Banerji, 1974). It was acknowledged that few manufacturing industries have low technical development with less rate of production, while others have higher productivity and all the qualities of being technologically advanced. As per Rothwell (1982), labor turnover has both immediate and concealed expenses to the industry since it leads to wastage of its HR. It was reasoned that no single 
industry is prone to make all the feasible changes. The choice should be governed by variables like, the kind of work and the time and costs included. Togo (2002) investigated the concurrence of labor capacity in manufacturing industries, utilizing transition matrix. The outcomes demonstrated that manufacturing industries do not show an example of merging and the commercial ventures with generally high work yield will have a bipolar allocation of labor. It was inferred that, more evidence is needed in order to examine that this situation is frequent.

According to Pattnayak and Thangavelu (2005) the total factor productivity growth is enhanced after the monetary changes in the majority of commercial enterprises. As the economy changes, it allows more inflow of funds into the economy. Moreover, the use of foreign investments might make profitable promises to the modern framework. Holzl and Reinstaller (2007) built up a methodology for total and sectoral work efficiency and demand fluctuations. They stated that for few industries demand acts as an important variable to drive the sectoral development. The efficiency of labor and demand pull is closely related to development rate of jobs and development across industries. Undoubtedly, industry statistics are not quickly identified with short and medium run changes in profitability and demand.

\subsubsection{Customer expectations}

Customer satisfaction is an important term widely used in business and marketing. It is defined as the number of clients or percentage of total customers, whose recorded experience with a company, its products and services surpasses indicated satisfaction goals.

Customer loyalty is seen as a crucial factor and it has turned into an important component of marketing technique. Moreover, it provides an indication of customer's purchase intentions. The data related to customer satisfaction is among the most regularly collected criterion of market perceptions. Two important uses of customer satisfaction survey are:

- the data sends a message about the significance of tending to clients and guaranteeing that they have a positive experience with the company's products and services.

- although sales can show current performance of an organization, satisfaction level is perhaps the best pointer of how likely the customers will have next purchases later on.

The various findings by authors on customer satisfactions related to sustainable development are discussed in the following section:

As per Peterson and Wilson (1992), assessment of customer expectations exhibit confusion and reflects diverse outcomes. They supported the idea that fulfilling customer expectations is a fundamentally sound conduct. Unfortunately, an evaluation criterion of customer satisfaction is not especially informative or analytic, primarily because of their remarkable distributional aspects. It is exceptionally hard to have a true satisfaction level unless neutral measuring devices come into practice. Therefore, more efforts are needed to improvise the assessment techniques of customer satisfaction.

According to Mittal and Lassar (1998) customer loyalty acts as a way to long-term profits. Supervisors should recognize whether the specialized change is essential for the organizations in their administration operations. This investigation may guide a service company's interest in suitable quality activities. Gupta et al. (2000) suggested a model for settlement amongst customer demand satisfaction and manufacturing costs. In the recommended model, the production choices are made before demand acknowledgment and on the other side, the inventory network choices are postponed. As per Heikkila (2002) quickly developing commercial enterprises accomplish great consumer loyalty together with effectiveness in supply chain management (SCM). Satisfying relationship amongst the customer and the retailer leads to stable information flows, and demand information flows thus add to high profitability. It was concluded that organizations in the developing businesses ought to continually prosper their supply chain effectiveness.

An unpredictable situation is formulated by fast changes in customer's needs, struggle and innovation. Accordingly, producers are improving adaptability over the value chain. Manufacturing flexibility is the ability to make a combination of things in the amounts that customers demand while maintaining proficiency. It has been 
noticed that, volume and mix flexibility have firm and clear connection with customer satisfaction. It was concluded that flexible manufacturing competencies supports the company's flexible proficiencies, i.e. volume flexibility and mix flexibility. These adaptable capacities, thus, upgrade consumer loyalty (Zhang et al., 2003).

As per Helgesen (2007), demand pull oriented companies are linked to customer loyalty and business advantages over the long term. He focused on the productivity parts of marketing. It was inferred that the own advantage of the business additionally must be satisfied, i.e., the clients should be benefited in one way or the other. An extensive system for target planning for customer satisfaction in the product development process was proposed by Yadava and Goel (2008). Technical exercises were conducted to have a connection among corporate and engineering decisions. Customer satisfaction targets were built by thorough examination of business studies. These objectives were changed to target building measurements utilizing regression procedures.

A rapidly growing competition and increasing needs of customers encourage manufacturing companies to have customizability in product development. Product concept flexibility (CF) and prototype flexibility (PF) emerged as efficient methods to instantly promote latest products to match ambitious tests and fulfill consumer needs. Product CF empowers companies to completely look at different item definitions and thoughts. Product PF permits companies to collect customer's feedback and examine design utility. This exploration checks the intervening, directing and additive models that relate product CF, product PF and consumer loyalty. The outcomes demonstrated that organizations with high product CF will probably be benefited from PF than from companies with low product $\mathrm{CF}$, and that product CF and PF will anticipate customer satisfaction separately and additively. Analysis of the largescale survey data gave initial results about particular methods that CF and PF combine to influence customer satisfaction. However, CF and PF are just two items in a large number of variables that affect consumer loyalty; while other factors were not taken into consideration (Zhang et al., 2009).

\section{CONCLUSIONS}

A review has been conducted on different issues that have crucial role in accomplishing core competencies in manufacturing industries. The paper elaborates different aspects of demand pull using research executed by various authors in the past. The study has looked into the writings and issues identified with feasible improvements in various industries and presents different models and frameworks for the same. It is observed that DP provides steady improvement in the development activities of manufacturing industries. The points discussed in the literature review plays an important role in optimizing the cost and nature of product, and needs of the customer.

Furthermore, the study explores the compliance of products as per government regulations. The stringent implementation of policies by government leads to fluctuations in the demand. It motivates the industries to enhance technological capabilities to meet the demand and it becomes necessary for an industry to fulfill the demand in time, to sustain in the market. In this paper, perspectives of different authors have been discussed and their contributions are summarized. Sustainable development is a multi dimensional concept. In the nutshell, productivity and customer satisfaction in an industry should be high enough to have sustainable development, thereby leading the organization to compete with others successfully in this highly competitive scenario. In this way, fulfilling the customer's needs as per the demand can turn out to be a significant methodology for manufacturing industries.

\section{REFERENCES}

[1] Aloi, M., Leite-Monteiro, M. and Lloyd-Braga, T. (2009), "Unionized labor markets and globalized capital markets", Journal of International Economics, Vol. 78, No. 1, pp. 149-153.

[2] Ashford, N.A. and Heaton, G.E. (1976), "Environmental and Safely Regulations: Reasons for their adoption and possible effects on technological innovation”, Journal of Environmental Policy and Law, Vol. 1, No. 4, pp. 172-176.

[3] Banerji, A. (1974), "Production functions for selected Indian industries", The Journal of Development Studies, Vol. 10, No. 2, pp. 213-229.

[4] Bastos, P., Monteiro, N.P. and Straume, O.R., (2009), "Firm heterogeneity and wages in unionized labour markets: Theory and evidence", Journal of Labour Economics, Vol. 16, No. 4, pp. 440-450.

[5] Blohmke, J. (2014), “Technology complexity, technology transfer mechanisms and sustainable development”, Journal of Energy for Sustainable Development, Vol. 23, pp. 237-246.

[6] Bogue, R. (2014), "Sustainable manufacturing: a critical discipline for the twenty-first century", Journal of Assembly Automation, Vol. 34, No. 2, pp. 117-122.

[7] Bohnsack, R., Pinkse, J. and Kolk, A. (2014), "Business models for sustainable technologies: Exploring business model evolution in the case of electric vehicles”, Journal of Research Policy, Vol. 43, No. 2, pp. 284-300. 
[8] Brundtland (1987), “Our Common Future”, Journal of World Commission on Environment and Development, Oxford University Press, Oxford.

[9] Chau, P.Y.K. and Tam, K.Y. (2000), “Organizational adoption of open systems: a 'technology-push, need-pull' perspective”, Journal of Information and Management, Vol. 37, No. 5, pp. 229-239.

[10] Chryssolouris, G., Mavrikios, D. and Mourtzis, D. (2013), “Manufacturing Systems: Skills and Competencies for the Future”, Procedia of CIRP, Vol. 7, pp. 17-24.

[11] Costantini, V., Crespi, F., Martini, C., Pennacchio, L. (2015), "Demand-pull and technology-push public support for eco-innovation: The case of the biofuels sector”, Journal of Research Policy, Vol. 44, No. 3, pp. 577-595.

[12] Gil-Garcia, J.R., Helbig, N. and Ojo, A. (2014), "Being smart: Emerging technologies and innovation in the public sector", Journal of Government Information Quarterly, Vol. 31, No. 1, pp. I1-I8.

[13] Gupta, A., Maranas, C.D. and McDonald, C.M. (2000), "Mid-term supply chain planning under demand uncertainty: customer demand satisfaction and inventory management”, Journal of Computers and Chemical Engineering, Vol. 24, No. 12, pp. 2613-2621.

[14] Hannon, M.J., Foxon, T.J. and Gale, W.F. (2015), “'Demand pull’ government policies to support Product-Service System activity: the case of Energy Service Companies (ESCos) in the UK”, Journal of Cleaner Production, Vol. 108, Part A, pp. 900-915.

[15] Heikkila, J., (2002), "From supply to demand chain management: efficiency and customer satisfaction", Journal of Operations Management, Vol. 20, No. 6, pp. 747-767.

[16] Helgesen, O. (2007), "Customer accounting and customer profitability analysis for the order handling industry - A managerial accounting approach”, Journal of Industrial Marketing Management, Vol. 36, No. 6, pp. 757-769.

[17] Holden, E., Linnerud, K. and Banister, D. (2014), "Sustainable development: Our Common Future revisited", Journal of Global Environmental Change, Vol. 26, pp. 130-139.

[18] Holzl, W., Reinstaller, A. (2007), "The impact of productivity and demand shocks on structural dynamics: Evidence from Austrian manufacturing”, Journal of Structural Change and Economic Dynamics, Vol. 18, No. 2, pp. 145-166.

[19] Johnstone, N., Hascic, I., Popp, D. (2010), "Renewable Energy Policies and Technological Innovation: Evidence Based on Patent Counts”, Journal of Environmental and Resource Economics, Vol. 45, No. 1, pp. 133-155.

[20] Jovane, F., Yoshikawa, H., Alting, L., Boer, C.R., Westkamper, E., Williams, D., Tseng, M., Seliger, G. and Paci, A.M. (2008), “The incoming global technological and industrial revolution towards competitive sustainable manufacturing”, Journal of CIRP Annals Manufacturing Technology, Vol. 57, No. 2, pp. 641-659.

[21] Lommerud, K.E., Meland, F., Straume, O.R. (2012), "North-South technology transfer in unionised multinationals", Journal of Development Economics, Vol. 99, No. 2, pp. 385-395.

[22] Mittal, B., Lassar, W.M. (1998), “Why do customers switch? The dynamics of satisfaction versus loyalty”, Journal of Services Marketing, Vol. 12, No. 3, pp. 177-194.

[23] Lingens J. (2003), “The impact of a unionised labour market in a Schumpeterian growth model”, Journal of Labour Economics, Vol. 10, No. 1, pp. 91-104.

[24] Modesto, L. and Thomas, J.P. (2001), “An analysis of labour adjustment costs in unionized economies”, Journal of Labour Economics, Vol. 8, No. 4, pp. 475-501.

[25] Pattnayak, S.S., Thangavelu, S.M. (2005), "Economic reform and productivity growth in Indian manufacturing industries: an interaction of technical change and scale economies”, Journal of Economic Modelling, Vol. 22, No. 4, pp. 601-615.

[26] Peterson, R.A., Wilson, W.R. (1992), "Measuring Customer Satisfaction: Fact and Artifact”, Journal of the Academy of Marketing Science, Vol. 20, No. 1, pp. 61-71.

[27] Pham, D.T. and Thomas, A.J. (2012), “Fit manufacturing: a framework for sustainability”, Journal of Manufacturing Technology Management, Vol. 23, No. 1, pp. 103-123.

[28] Rothwell, S. (1982), "Productivity improvement Through Reduced Labour Turnover”, Journal of Long Range Planning, Vol. 15, No. 2, pp. 67-76.

[29] Rothwell, R. (1992), "Industrial innovation and government environmental regulation: Some lessons from the past", Journal of Technovation, Vol. 12, No. 7, pp. 447-458.

[30] Rout, U.K. (2011), "Regional demand-pull scenarios and cost-effective emission mitigation”, Clean Technologies and Environmental Policy, Vol. 13, No. 5, pp. 719-729.

[31] Sastry, T. (2011), "Exploring the role of business in society”, Journal of IIMB Management Review, Vol. 23, No. 4, pp. $246-256$.

[32] Singh, R., Debnath, R.M. (2012), "Modeling sustainable development: India’s strategy for the future”, World Journal of Science, Technology and Sustainable Development, Vol. 9, No. 2, pp. 120-135.

[33] Taylor, M.R., Rubin, E.S., Hounshell, D.A. (2005), "Control of $\mathrm{SO}_{2}$ emissions from power plants: A case of induced technological innovation in the U.S.”, Journal of Technological Forecasting and Social Change, Vol. 72, No. 6, pp. 697-718.

[34] Togo, K. (2002), "Productivity convergence in Japan's manufacturing industries”, Journal of Economics Letters, Vol. 75, No. 1, pp. 61-67.

[35] Wagner, M., Bachor, V., Ngai, E.W.T. (2014), "Engineering and technology management for sustainable business development: Introductory remarks on the role of technology and regulation”, Journal of Engineering and Technology Management, Vol. 34, pp. 1-8.

[36] Walker, R.A., (1993), “The Hidden Dimension of Industrialization: An expanding division of labour”, Journal of Futures, Vol. 25, No. 6, pp. 673-693.

[37] Yadav, P. (2012), “India’s changing trade pattern in the process of globalization”, Procedia of Social and Behavioral Sciences, Vol. 37, pp. 157-166.

[38] Yadava, O.P., Goel, P.S. (2008), “Customer satisfaction driven quality improvement target planning for product development in automotive industry”, International Journal of Production Economics, Vol. 113, No. 2, pp. 997-1011.

[39] Zhang, Q., Vonderembse, M.A., Lim, J. (2003), "Manufacturing flexibility: defining and analyzing relationships among competence, capability, and customer satisfaction”, Journal of Operations Management, Vol. 21, No. 2, pp. 173-191.

[40] Zhang, Q., Vonderembse, M.A., Cao, M. (2009), "Product concept and prototype flexibility in manufacturing: Implications for customer satisfaction”, European Journal of Operational Research, Vol. 194, No. 1, pp. 143-154. 